\title{
Determining Factors for Educating Students for Choosing to Work for Foreign Units: Absence of Self-Efficacy
}

Nguyen Thanh Hoang ${ }^{1}$

Dinh Tran Ngoc Huy ${ }^{2}$

\author{
Journal for Educators, Teachers and Trainers, Vol. 12 (2)
}

https://jett.labosfor.com/

Date of reception: 18 Oct 2020

Date of revision: 16 Jan 2021

Date of acceptance: 15 April 2021

Nguyen Thanh Hoang, Dinh Tran Ngoc Huy (2021). Determining Factors for Educating Students for Choosing to Work for Foreign Units: Absence of Self-Efficacy. Journal for Educators, Teachers and Trainers, Vol. 12(2). 11 - 19.

${ }^{1}$ The University of Social Sciences and Humanities National University of Ho Chi Minh City, Vietnam.

${ }^{2}$ Banking University HCMC, Ho Chi Minh city Vietnam - International University of Japan, Niigata, Japan 


\title{
Determining Factors for Educating Students for Choosing to Work for Foreign Units: Absence of Self-Efficacy
}

Nguyen Thanh Hoang ${ }^{1}$, Dinh Tran Ngoc Huy ${ }^{2}$

${ }^{1}$ The University of Social Sciences and Humanities National University of Ho Chi Minh City, Vietnam.

${ }^{2}$ Banking University HCMC, Ho Chi Minh city Vietnam - International University of Japan, Niigata, Japan

Email ID: hoangnguyenfir@hcmussh.edu.vn, Dtnhuy2010@gmail.com

\begin{abstract}
Educating our students in developing countries such as Vietnam is becoming necessary. So first of all, this study aims to identify factors that impact on students' decision to work for a foreign company for those who are studying in the field of social sciences and humanities. Based on 508 responses, the results from linear regression analysis shows that Self-Interests, Self-Outcome Expectations (internal factors), University's Gains, and References (external factors) were factors that affect student workplace choice. Meanwhile, the factor of capacity ("Self-efficacy") to perform the task ("Working environment") has no statistical relationship. This result suggests for educational managers, business managers in general and foreign enterprises in particular to coordinate vocational education for students.
\end{abstract}

Keywords: Workplace choice, Graduates' career choice, work for foreign enterprises, FDI.

\section{INTRODUCTION}

Jobs -are always a concern for many people, especially students.

From the perspective of society, most graduates face difficulties in finding suitable and stable jobs. One of the reasons is that they lack specific career orientation in choosing a specialty that suits their abilities. Some students choose disciplines that do not match their capacity or respond to labour market development trends. Businesses are very interested in recruiting graduates for their knowledge, ability to collaborate, working skills, communication skills, knowledge about the corporate cultural environment and cooperation, industrial working style and foreign language skills. This shows that students need to be prepared with the knowledge and skills to respond to the needs of the market.

From the perspective of students, the choice of workplace is not a simple matter. Many questions are raised, such as whether to work in an urban centre or their hometown; work for a small company or a large corporation; work for government agencies or private companies; work for domestic or foreign businesses; start a business; or go abroad to work. Their intention to choose a workplace is influenced not only by their professional knowledge (field of study), soft skills, and requirements from employers but also by the working environment, conditions for a career path, and their family's expectations as well.

Today, the presence of foreign enterprises and international organizations (referred to as foreign units) in the domestic labour market provides a diversity of workplaces choices. This study aims to identify factors that influence the choice of working for foreign organizations by students who study in the field of humanities and social sciences. This field provides students with a set of skills for a broad range of professional paths, including business, communication, politics, languages, literature, history, education, psychology, anthropology and international relations. Graduates gain a solid liberal arts foundation and detailed exploration of the theoretical aspects of the field. This study helps educators develop training programs that can help students immediately access the labour market after graduation. In addition, students also understand themselves better in order to prepare for gaining new knowledge, experience and skills.

\section{LITERATURE REVIEW}

The theories of career choice and development have been developed by many researchers from the 1960s to the present. Some theories are widely accepted and applied such as Self-Concept Theory (Super 1963, 1964, 1980, 1990); Theory of Vocational Choice (Holland, 1973, 1985, 1992, 1997); Theory of Circumscription and Compromise (Gottfredson, 1981, 1996, 2002, 2005); Theory of Work Adjustment (Dawis \& Lofquist, 1984, 1991, 2002, 2005); and Social Cognitive Career Theory (Lent, Brown and Hackett, 2002; Lent, 2005).

Super's Self-Concept Theory focused on explaining individual's career development which depended on each life-role corresponding to each life-stage of a person. At each stage, there are four to five tasks to be performed. Career choices usually begin in the second stage of ages 14 to 24, called Exploration. At this stage, individuals choose a career based on their own personal interests and capacities, which are obtained via classes, working 
experiences, and hobbies. From Holland's perspective, the occupational choice of individuals depends on their type of personality. Each personality type will correspond to a certain number of occupations. He identified six RIASEC personality types, including Realistic (R), Investigative (I), Artistic (A), Social (S), Enterprising (E), or Conventional (C). Thus, in order to choose a career, the person first discovers his / her personality. Gottfredson analyzed an individual's career choice during the first 20 years of life through four developmental processes: cognitive development; self-creation; circumscription; and compromise. In general, individuals choose a job that is compatible with their perceptions of themselves. These perceptions are related to their self-directed development, their limitations such as their academic ability, personal experience, costs, efforts, interests, and talents; as well as external impacts that they cannot control such as labour market conditions and available training programs. Theory of Work Adjustment (TWA) developed by Dawis and Lofquist reflected the correspondence between a person's needs and competencies with the working environment. A proper match will create job satisfaction. To get satisfaction, the working environment must satisfy the needs of workers. In turn, employees must have the ability to complete tasks. In addition, workers have to make adjustments to create a fit between the individual's work personality and the work environment. In other words, people will choose the occupation that they have enough skills and capacity to perform and in which their needs will be met. Social Cognitive Career Theory (SCCT) has been developed with an integrated model of three continuous stages which range from career interests to career choice (Choice Goals and Choice Actions) and career development (Performance Domains and Attainments). The three key factors in this model are Self-Efficacy Expectations, Outcomes Expectation and Personal Goals. Self-Efficacy Expectations derived from Bandura's Self-Efficacy (1977) were beliefs about one's ability to perform a specific behaviour. Outcomes Expectations were the expectations of achievement while performing a behavior. Personal Goals are objectives that the individual sets out in proportion to their competencies and expected results. In the SCCI model, Self-Efficacy and Outcomes Expectation were two factors that affect the whole process from Interests (Interest Model) $\rightarrow$ Choice Goals, Choice Actions (Choice Model) $\rightarrow$ Performance Domains and Attainments (Performance Model). In addition, both Choice Goals and Choice Action are influenced by external factors (Proximal Environmental Influences). Thus, the choice of career will be influenced by four factors: Self-Efficacy Expectations, Outcomes Expectation, Interests and Proximal Environmental Influences.

In summary, career choice was a process based on many dimensions. According to the five major theories, the individual was central in relation to career choice. The decisions of individuals were based on self-awareness, including internal competencies in knowledge, skills, work experience; personality; psychological needs; interests; and expectations for career development, work environment and income opportunities. In addition, external factors also contribute to individual decisions. This study inherits from previous studies on the decisive role of job seekers in career choice. A student's workplace choice model is proposed in the Figure 1:

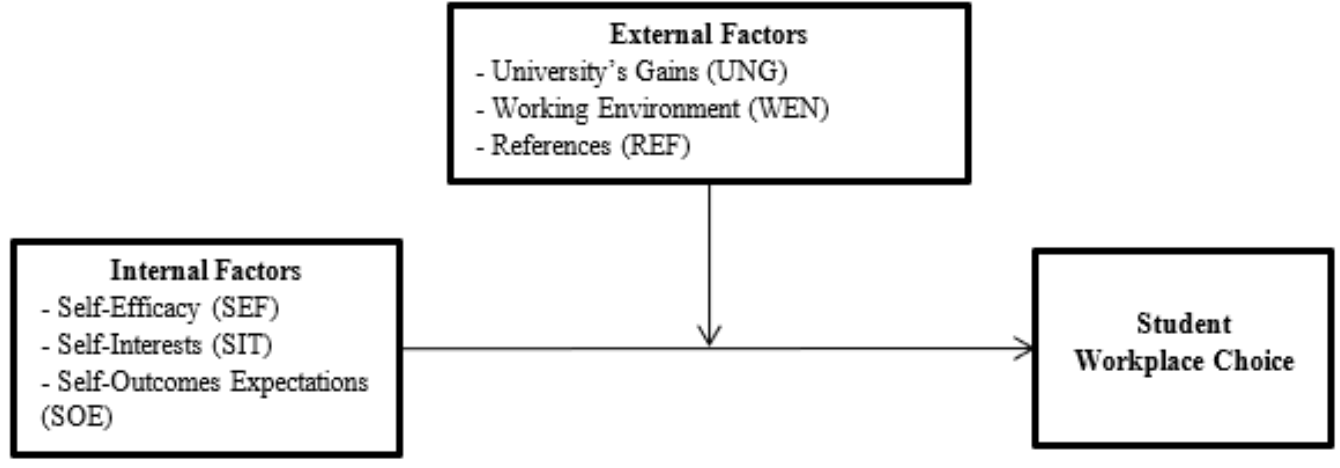

Fig.1: Student's Workplace Choice Model

To choose to work for foreign units, students will first consider their ability to conduct the job requirements and tasks (Self-Efficacy). This ability can include intelligent ability, professional qualifications, soft skills and work experience. Students choose to work for a foreign unit because of personal concerns (Self-Interests). They like to work in an international environment, a path to career development, professional development, managerial skills development and overcoming challenges. Working for a foreign unit, students certainly have high outcome expectations that may have the opportunity to live abroad to discover new things. These expectations are set in comparison with working at a local private company or government agency. Students believe that by working in a foreign unit they will receive a higher salary, higher income, more benefits on bonuses and insurance. Besides, the opportunity to apply experience into practical work is a factor that students care about. And Dinh Tran Ngoc Huy, Pham Ngoc Van, \& Nguyen Thi Thu Ha (2021) also stated that Vietnam labor market need to be trained more to increase higher competitiveness compared to other Asian countries. Their skills such as group work, individual and computer capabilities need to be improved during and to prepare for jobs in EVFTA. 
Because job seekers play a decisive role, external actors are only moderators rather than direct agents as Lent, Brown, and Hackett (2002) proposed. In this study, the university's gains are one of external affects. Choosing to work for a foreign unit will be easier once students are equipped with knowledge and skills in educated knowledge and specialized knowledge, from relevant subjects in particular. Students tend to choose jobs based on their favorite subject or extensive knowledge. Besides, by studying in a school that is highly accredited for that specialty, students are more confident in choosing a workplace, especially foreign units. The working environment is a key factor influencing students' choice to work for a foreign unit. They assume that the working environment of foreign units is very professionally managed; any opportunities are equal for everyone; employees are assigned suitable placements matched with expertise and capacity; most employees are quality employees, and colleagues are supportive and friendly. Furthermore, the reputation of the foreign unit is one of the dominant factors in the student's choice. At the same time, references such as word of mouth, guidance from parents, friends, counselors and idols may influence the student's choice. Family financial condition is also a contributing factor in the decision-making process.

Last but not least, Vu Thi Thuy Dung, Le Ngoc Nuong and Dinh Tran Ngoc Huy et al (2021) stated that Employment after graduation is always an issue that is of concern not only for students but also for families, schools and society. Having a job in the right career training is always a dream of most not only for graduate students but also for those who are still sitting on university lecture chairs.

\section{RESEARCH METHODOLOGY}

This study applied a quantitative approach. The survey was conducted through a questionnaire posted on Google Docs. Links were posted on media such as the faculties' fan page, closed groups on Facebook and personal emails. Subjects were students of the University of Social Sciences and Humanities (USSH), Vietnam National University of Ho Chi Minh City, and University of Finance and Marketing (UFM) in Ho Chi Minh City.

The questionnaire consisted of 2 parts. Part 1 was the respondent's identification information, including school year, faculty, working experience, and intention to work for foreign units. Part 2 was questions measured by the 5-level Likert scale. Dependent variable - "Student's Workplace Choice" (SWC) had three indicators. The three independent variables were 1) Self-Efficacy (SEF) (4 indicators), 2) Self-Interests (SIT) (7 indicators), 3) SelfOutcome Expectations (SOE) (5 indicators). The three moderating variables were 1) University's Gains (UNG) (4 indicators); 2) Working Environment (WEN) (6 indicators), and 3) References (REF) (5 indicators).

The survey was conducted from February to April 2019. In total 611 responses were received, of which 554 were valid responses, except 57 answers of non-USSH and non-UFM students. Among 554 responses, 508 students had an intention to work for foreign units (91.87\%). According to Tabachnick and Fidell (1996), the minimum sample size must be $298(\mathrm{n}=50+8 * \mathrm{~m}=50+8 * 31)$. In this study, the actual sample size was 508 , two thirds more than the required sample size.

For data analysis, the study followed step-by-step: Descriptive analysis, Reliability test, Validity test, and Regression test.

\section{RESULTS AND DISCUSSION}

Within the total of 508 respondents, 246 students were at USSH, 48.4\%. They mainly came from the International Language Faculty (such as Russian, English, German, Italian, Spanish, Chinese, Korean, and Japanese), International Relations Faculty and Social Work Faculty. For UFM, 262 students (51.6\%) were majoring in the faculties of international business, business administration, accounting, banking and finance, and tourism. Students in the first year (freshman) was $15.9 \%$, sophomore: $21.9 \%$; junior: $34.8 \%$; senior: $26.0 \%$; and graduates: $1.4 \%$. Most students in years 3 and 4 had spent time doing internships or part-time jobs. However, only 114 students $(34.8 \%)$ had been work experience. Among the USSH students, those who had not done part-time jobs or internships were 3 times higher than the number of those with work experience (180 vs. 66). Meanwhile, nearly $41.2 \%$ of UFM students had work experience (See Table A1. Data Description of Respondents).

The data was tested reliability via the value of Cronbach's Alpha. According to Nunally and Burnstein (1994), the Cronbach's Alpha value must be greater than 0.6 and the observed variables with the variable-total correlation coefficient must be greater than 0.3. Two deleted items were Academic Achievement (SEF2) and Experience Application (SOE3). Table A2. Summary of Reliability Test represented the result of the reliability test.

The validity test was reflected by the Exploratory Factor Analysis (EFA). EFA is used to restructure variables based on strong correlation between constructs. According to Hoang Trong \& Chu Nguyen Mong Ngoc (2008), $0.5 \leq \mathrm{KMO} \leq 1$ is accepted and Bartlett test has Sig. < 0.05. In addition, Cumulative \% of Extraction Sums of Squared Loadings is greater than 50\% (Gerbing \& Anderson, 1998). The 26 items of six independent variables were categorized into six similar groups. Table A3. Summary of Validity Test represented the result of the validity test.

In order to choose the best model for determining the factors affecting students' choice to work for foreign units, we experimented with many specifications.

The first specifications used pooled data: 
The basic specification (1.1) was to test the influence of internal factors: X1-Self-Efficacy (SEF), X2-SelfInterests (SIN), X3-Self-Outcome Expectations (SOE) on Y1-Student Workplace Choice (SWC).

$Y 1=\beta_{0}+\beta_{1} X 1+\beta_{2} X 2+\beta_{3} X 3+\alpha$

The extended specifications $(1.2 .1,1.2 .2,1.2 .3)$ added the external factor: X4-Working Environment (WEN), X5University's Gains (UNG), and X6-References (REF) in turn to the basic specification.

$Y 1=\beta_{0}+\beta_{1} X 1+\beta_{2} X 2+\beta_{3} X 3+\beta_{3} X 4+\alpha$

$Y 1=\beta_{0}+\beta_{1} X 1+\beta_{2} X 2+\beta_{3} X 3+\beta_{3} X 4+\beta_{3} X 5+\alpha$

$Y 1=\beta_{0}+\beta_{1} X 1+\beta_{2} X 2+\beta_{3} X 3+\beta_{3} X 4+\beta_{3} X 5+\beta_{3} X 6+\alpha$

The second specifications were a split variable ID (proxy for identification) to specify students from USSH and UFM. Thus, we had specifications of $2 \mathrm{a}$ (2a.1, 2a.2.1, 2a.2.2, 2a.2.3) for USSH and 2b for UFM (2b.1 (2b.2.1, 2b.2.2, 2b.2.3)

According to Mooi and Sarstedt (2011), $\mathrm{R}^{2}$, adjusted $\mathrm{R}^{2}$ and F-value are used to assess the model fit. The $\mathrm{R}^{2}$ value indicates the association between the dependent variable and the independent variables. The higher the value, the more the variation of the dependent variable is explained by the variation in the independent variable. Although a higher $\mathrm{R}^{2}$ means a better model fit there is no rule for a minimum accepted value. It differs and depends on the research area. The adjusted $\mathrm{R}^{2}$ is useful for comparing regression models which are similar dependent variables. The model which has the highest adjusted $\mathrm{R}^{2}$ should be collected. The F-test determines the significance of the overall model fit. Table A4 gave a summary of the specifications. The specification (1.1.3) had the highest adjusted $\mathrm{R}^{2}$; therefore, its result was counted.

Table 1 showed the regression result. The value of $R^{2}$, adjusted $R^{2}$ and F-value were $0.372,0.365$ and 49.393 respectively. This model is significant. In addition, the VIF (Variance Inflation Factor) $<10$, there is no multicollinearity.

Table 1: The regression results

\begin{tabular}{|c|c|c|c|c|c|c|}
\hline \multicolumn{7}{|c|}{ Model Summary } \\
\hline Model & $\mathrm{R}$ & R Square & \multicolumn{2}{|l|}{ Adjusted R Square } & \multicolumn{2}{|c|}{ Std. Error of the Estimate } \\
\hline 1 & $.602^{\mathrm{a}}$ & .362 & .355 & & \multicolumn{2}{|c|}{1.50537} \\
\hline \multicolumn{7}{|c|}{ a. Predictors: (Constant), F_REF, F_SEF, F_SIT, F_UNG, F_SOE, F_WEN } \\
\hline \multicolumn{7}{|c|}{ ANOVA $^{\mathrm{a}}$} \\
\hline \multicolumn{2}{|c|}{ Model } & Sum of Squares & df & Mean Square & $\mathrm{F}$ & Sig. \\
\hline \multirow[t]{3}{*}{1} & Regression & 644.931 & 6 & 107.488 & 47.433 & $.000^{\mathrm{b}}$ \\
\hline & Residual & 1135.329 & 501 & 2.266 & & \\
\hline & Total & 1780.260 & 507 & & & \\
\hline \multicolumn{7}{|c|}{ a. Dependent Variable: F_SWC } \\
\hline \multicolumn{7}{|c|}{ b. Predictors: (Constant), F_REF, F_SEF, F_SIT, F_UNG, F_SOE, F_WEN } \\
\hline
\end{tabular}

\begin{tabular}{|c|c|c|c|c|c|c|c|c|}
\hline \multicolumn{9}{|c|}{ Coefficients $^{\mathrm{a}}$} \\
\hline \multirow{2}{*}{\multicolumn{2}{|c|}{ Model }} & \multicolumn{2}{|c|}{ Unstandardized Coefficients } & \multirow{2}{*}{$\begin{array}{l}\text { Standardized Coefficients } \\
\text { Beta }\end{array}$} & \multirow[t]{2}{*}{$\mathrm{t}$} & \multirow[t]{2}{*}{ Sig. } & \multicolumn{2}{|c|}{ Collinearity Statistics } \\
\hline & & $\mathrm{B}$ & Std. Error & & & & Tolerance & VIF \\
\hline \multirow[t]{7}{*}{1} & (Constant) & 3.231 & .601 & & 5.380 & .000 & & \\
\hline & F_SOE & .076 & .033 & .107 & 2.320 & .021 & .601 & 1.664 \\
\hline & F_SEF & .048 & .033 & .060 & 1.489 & .137 & .788 & 1.270 \\
\hline & F_SIT & .144 & .040 & .158 & 3.592 & .000 & .655 & 1.527 \\
\hline & F_WEN & .041 & .026 & .079 & 1.580 & .115 & .515 & 1.943 \\
\hline & F_UNG & .198 & .029 & .299 & 6.717 & .000 & .641 & 1.560 \\
\hline & F_REF & .067 & .020 & .129 & 3.320 & .001 & .847 & 1.181 \\
\hline
\end{tabular}

In this model, Self-Interests (SIT), Self-Outcome Expectations (SOE), University's Gains (UNG), and References (REF) had a positive relationship to Student Workplace Choice (SWC); while Self-Efficacy (SEF) and Working Environment (WEN) had no statistical significance. The value of B shows the influence of a 1-unit change in the independent variable on the dependent variable; while the value of beta reflects the extent of influence of the independent variable. The highest absolute value, the strongest variable effects the dependent variable. In this model, if the students strongly recognize their interests and expectations, the possibility of choosing to work for a foreign unit increases by 0.144 and 0.076-unit respectively. Besides, the increase in University's Gains and References' convincing, the choice to work for a foreign unit increases by 0.198 and 0.067 -unit respectively. Based on the value of beta, the University's Gains (0.299) had the strongest effect on student workplace choice. The order of influence was as following:

$\mathrm{SWC}=3.231+.299 \mathrm{UNC}+.158 \mathrm{SIT}+.129 \mathrm{REF}+.107 \mathrm{SOE}+.601$ 
Among the three core factors that represented personal abilities (SEF), interests (SIT) and expectations (SOE), the interests and expectations had a stronger impact on student's choices. At this age (around 17-22 years old), students had just escaped 12 years of being bound by the curriculum in high school. In an open environment of university, students made their own decisions based on their own interests (e.g., professional development, skills development, hobbies, and overcoming challenges) and expectations (e.g., high income, bonus, insurance). Among the three external factors that influence students' choices (gains from universities (UNG), work environment (WEN) and orientation from those around them (REF)), gains from universities and references had the stronger impact. In particular, gains from universities such as professional knowledge, specialized knowledge, favourite subjects and reputation of the school had the most powerful impact, stronger than the internal factors mentioned above. This showed that students recognized the full worth of an appropriate training program that gave them the ability, capacity, skills and experience for their career choice. Even at an adult age, everyone will need to listen to advice for things they have not yet experienced. Therefore, the impact of the students' choice was inevitably influenced by family, friends, teachers, idols and family economic situation.

The non-significance of self-efficacy might explain that the students might not aware the importance of their own capacity. They were not entirely confident in their own abilities and had not yet fully discovered their abilities. They still need time to improve academic abilities, skills, experience and knowledge. For the working environment, students thought highly of fairness and transparency in management as well as promotion opportunities. They appreciated a work environment where they had chances to learn from competent and friendly colleagues. However, this issue might not strongly influence on their thinking.

\section{CONCLUSION}

It is conceivable that students choose to work for foreign units because they interest and expect good prospects in the future. This choice is strongly influenced by their belief in the knowledge they receive from the university as well as the advice from those around them.

An important piece of the puzzle is missing: the capacity to accomplish tasks. Students are either too confident in their own abilities to be able to complete any task; or students themselves do not really understand what they have and what they do not have yet. The research result supports the connection between universities and enterprises in labor training.

Finding a job is not just for a job or for an income; it is a process of discovering oneself and finding meaning in life. Therefore, as job seekers students must recognize the goal of life to nurture interests, to enrich outcome expectations and to build up capacity to catch opportunities. The education institutes should revise, modify, and improve their curriculums to provide students enough competencies to meet the market's requirements and trends. At the same time, employers in general and foreign units in particular should improve the working environment to attract high quality employees.

The issue of career choice is developed along with time and changes in society. Therefore, the topic is forever ripe for studying.

Limitation of research: We need to expand further analysis on solutions for students in post-graduation to enter into FDI firms effectively.

\section{REFERENCES}

1. Anderson, J. C. (1988). Structural equation modeling in practice: A review and recommended twostep approach. Psychological Bulletin, 103(3), 411-423.

2. Dinh Tran Ngoc Huy, Pham Ngoc Van, Nguyen Thi Thu Ha. (2021). Education and computer skill enhancing for Vietnam laborers under industry 4.0 and Evfta agreement, Elementary education online, 20(4): 1033-1038. Doi: 10.17051/ilkonline.2021.04.112

3. Dinh Tran Ngoc Huy, \& Dinh Tran Ngoc Hien. (2010). The backbone of European corporate governance standards after financial crisis, corporate scandals and manipulation, Economic and Business Review, 12(4).

4. Dung Vu Thi Thuy, Dinh Tran Ngoc Huy, Vu Thi Kim Anh, Nguyen Ngoc Thach, Hoang Thanh Hanh. (2021). Quality of education of ethnic minority communities in vietnam - problems and recommendations, Elementary education online, 20(4): 600-605. Doi: 10.17051/ilkonline.2021.04.65

5. Hoang Thanh Hanh, Dinh Tran Ngoc Huy, \& Nguyen Thi Thanh Phuong. (2020). Impact of Macro Economic Factors and Financial Development on Energy Projects - Case in ASEAN Countries, Management, 24(2). DOI:10.2478/manment-2019-0051

6. Huy, D.T.N. (2015). The Critical Analysis of Limited South Asian Corporate Governance Standards After Financial Crisis, International Journal for Quality Research, 9(4): 741-764.

7. Huy, D.T.N. (2012). Estimating Beta of Viet Nam listed construction companies groups during the crisis, Journal of Integration and Development, 15 (1), 57-71 
8. Huy, D. T.N., Loan, B. T., and Anh, P. T. (2020). Impact of selected factors on stock price: a case study of Vietcombank in Vietnam, Entrepreneurship and Sustainability Issues, 7(4), pp. 27152730. https://doi.org/10.9770/jesi.2020.7.4(10)

9. Le Thi Thanh Huong, Do Thu Huong, Dinh Tran Ngoc Huy, Nguyen Thu Thuy. (2021). Education for students to enhance research skills and meet demand from workplace - case in vietnam, Elementary education online, 20(4): 606-611. Doi: 10.17051/ilkonline.2021.04.66

10. Leung, S. A. (2008). Chapter 6. The Big Five Career Theories. In J. A. Editors: Athanasou, International Handbook of Career Guidance (pp. 118-132). Springer Science + Business Media B.V.

11. Mooi, E., \& Sarstedt, M. (2011). A Concise Guide to Market Research. The process, data, and methods using IBM SPSS statistics. Heidelberg Dordrecht: Springer

12. Ngoc, H. T. (2008). Phan tich du lieu nghien cuu voi SPSS. Ho Chi Minh: Hong Đuc.

13. Nunnally, J. B. (1994). The Assessment of Reliability. Psychometric Theory, 248-292.

14. Pham Minh Dat, Nguyen Duy Mau, Bui Thi Thu Loan, \& Dinh Tran Ngoc Huy. (2020). Comparative China Corporate Governance Standards after Financial Crisis, Corporate Scandals and Manipulation, Journal of Security and Sustainability Issues, 9(3): 931-941. https://doi.org/10.9770/jssi.2020.9.3(18)

15. Tabachnick, B. G. (1996). Using Multivariate Statistics (3rd ed.). New York : Harper Collins.

16. Vu Thi Thuy Dung, Le Ngoc Nuong, Dinh Tran Ngoc Huy, Nguyen Ngoc Thach, Nguyen Thu Thuy. (2021). Enhancing the capabilities of students after graduation - a case study at university of economics and business administration - thai nguyen university, vietnam, Elementary education online, 20(4): 592-599. Doi: 10.17051/ilkonline.2021.04.64

\section{APPENDIX}

Table A1: Data Description of Respondents

\begin{tabular}{|c|c|c|c|c|c|c|c|c|c|}
\hline & \multicolumn{2}{|c|}{ Frequency } & \multicolumn{2}{|c|}{ Percent } & \multicolumn{2}{|l|}{ Mean } & \multicolumn{2}{|l|}{ Std Dev } \\
\hline & & USSH & UFM & USSH & UFM & USSH & UFM & USSH & UFM \\
\hline \multirow[t]{6}{*}{ Year in } & Freshman & 53 & 28 & 21.5 & 10.7 & \multirow[t]{6}{*}{2.38} & \multirow[t]{6}{*}{3.10} & \multirow[t]{6}{*}{.964} & \multirow[t]{6}{*}{1.016} \\
\hline & Sophomore & 79 & 32 & 32.1 & 12.2 & & & & \\
\hline & Junior & 82 & 95 & 33.3 & 36.3 & & & & \\
\hline & Senior & 32 & 100 & 13.0 & 38.2 & & & & \\
\hline & Bachelor & 0 & 7 & 0.0 & 2.7 & & & & \\
\hline & Total & 246 & 262 & 100.0 & 100.0 & & & & \\
\hline \multirow[t]{3}{*}{ Internship } & Yes & 66 & 111 & 26.8 & 42.4 & \multirow[t]{3}{*}{1.73} & \multirow[t]{3}{*}{1.58} & \multirow[t]{3}{*}{.444} & \multirow[t]{3}{*}{.495} \\
\hline & No & 180 & 151 & 73.2 & 57.6 & & & & \\
\hline & Total & 246 & 262 & 100.0 & 100.0 & & & & \\
\hline
\end{tabular}

Table A2: Summary of Reliability Test

\begin{tabular}{|l|l|l|}
\hline & $\begin{array}{l}\text { Cronbach's } \\
\text { Alpha }\end{array}$ & $\begin{array}{l}\text { Cronbach's Alpha if } \\
\text { Item Deleted }\end{array}$ \\
\hline SWC & 0.713 & \\
\hline SWC 1 & & 0.653 \\
\hline SWC2 & & 0.572 \\
\hline SWC3 & & 0.65 \\
\hline SEF & 0.682 & \\
\hline SEF1 & & .570 \\
\hline SEF2 & & $.688^{*}$ \\
\hline SEF3 & & 0.579 \\
\hline SEF4 & & 0.625 \\
\hline SIT & 0.746 & \\
\hline SIT1 & & 0.739 \\
\hline SIT2 & & 0.743 \\
\hline SIT3 & & 0.679 \\
\hline SIT4 & & 0.721 \\
\hline SIT5 & & 0.693 \\
\hline SIT6 & & 0.698 \\
\hline SIT7 & & 0.73 \\
\hline
\end{tabular}

\begin{tabular}{|l|l|l|}
\hline & $\begin{array}{l}\text { Cronbach's } \\
\text { Alpha }\end{array}$ & $\begin{array}{l}\text { Cronbach's Alpha if } \\
\text { Item Deleted }\end{array}$ \\
\hline SOE4 & & 0.782 \\
\hline SOE5 & & 0.758 \\
\hline UNG & 0.833 & \\
\hline UNG1 & & 0.799 \\
\hline UNG2 & & 0.785 \\
\hline UNG3 & & 0.802 \\
\hline UNG4 & & 0.766 \\
\hline WEN & 0.851 & \\
\hline WEN1 & & 0.826 \\
\hline WEN2 & & 0.817 \\
\hline WEN3 & & 0.839 \\
\hline WEN4 & & 0.818 \\
\hline WEN5 & & 0.827 \\
\hline WEN6 & & 0.828 \\
\hline REF & 0.719 & \\
\hline REF1 & & 0.695 \\
\hline REF2 & & 0.675 \\
\hline & & \\
\hline
\end{tabular}




\begin{tabular}{|l|l|l|}
\hline SOE & 0.822 & \\
\hline SOE1 & & 0.778 \\
\hline SOE2 & & 0.763 \\
\hline SOE3 & & $.843^{*}$ \\
\hline
\end{tabular}

\begin{tabular}{|l|l|l|}
\hline REF3 & 0.645 \\
\hline REF4 & 0.658 \\
\hline REF5 & 0.686 \\
\hline
\end{tabular}

Table A3. Summary of Reliability Test

Dependent variable: Student Career Choice

\begin{tabular}{|l|l|l|}
\hline \multicolumn{2}{|l|}{ KMO and Bartlett's Test } \\
\hline Kaiser-Meyer-Olkin Measure of Sampling Adequacy. & .672 \\
\hline Bartlett's Test of Sphericity & Approx. Chi-Square & 301.890 \\
\cline { 2 - 3 } & df & 3 \\
\cline { 2 - 3 } & Sig. & .000 \\
\hline
\end{tabular}

\section{Independent Variables}

\begin{tabular}{|l|l|l|}
\hline \multicolumn{2}{|l|}{ KMO and Bartlett's Test } \\
\hline Kaiser-Meyer-Olkin Measure of Sampling Adequacy. & .891 \\
\hline \multirow{3}{*}{ Bartlett's Test of Sphericity } & Approx. Chi-Square & 5254.067 \\
\cline { 2 - 3 } & df & 325 \\
\cline { 2 - 3 } & Sig. & 0.000 \\
\hline
\end{tabular}

\begin{tabular}{|l|l|l|l|l|l|l|}
\hline Rotated Component Matrix $^{\mathbf{a}}$ & \multicolumn{5}{l|}{ Component } & \multicolumn{5}{l|}{} \\
\hline & 1 & 2 & 3 & 4 & 5 & 6 \\
\hline suitable position assignment & .771 & & & & & \\
\hline managerial quality & .728 & & & & & \\
\hline friendly colleagues & .715 & & & & & \\
\hline quality employees & .641 & & & & & \\
\hline reputation of the company & .598 & & & & & \\
\hline fair and advanced opportunities & .580 & & & & & \\
\hline high income & & .784 & & & & \\
\hline bonus & & .771 & & & & \\
\hline insurance & & .733 & & & & \\
\hline well-paid & & .721 & & & & \\
\hline accepted accreditation & & & .794 & & & \\
\hline relevant subjects & & & .765 & & & \\
\hline favourite subjects & & & .745 & & & \\
\hline educated knowledge & & & .655 & & & \\
\hline friends & & & & .739 & & \\
\hline idols & & & & .705 & & \\
\hline family & & & & .644 & & \\
\hline family financial condition & & & & .626 & & \\
\hline counsellors & & & & .603 & & \\
\hline soft skills & & & & & .781 & \\
\hline personal experience & & & & & .710 & \\
\hline academic ability & & & & & .692 & \\
\hline career path orientation & & & & & .580 & \\
\hline working in global & & & & & .799 \\
\hline living abroad & & & & & .742 \\
\hline professional development & & & & & \\
\hline
\end{tabular}

Table A4: Summary of Specifications

\begin{tabular}{|c|c|c|c|c|c|c|c|c|c|c|c|c|c|c|c|}
\hline & \multicolumn{5}{|c|}{ POOLED DATA } & \multicolumn{5}{|c|}{ USSH } & \multicolumn{5}{|c|}{ UFM } \\
\hline & $\mathrm{R}^{2}$ & $\begin{array}{l}\text { Adjusted } \\
\mathrm{R}^{2}\end{array}$ & $\mathrm{~B}$ & Beta & Sig & $\mathrm{R}^{2}$ & $\begin{array}{l}\text { Adjusted } \\
\mathrm{R}^{2}\end{array}$ & B & Beta & Sig & $\mathrm{R}^{2}$ & $\begin{array}{l}\text { Adjusted } \\
\mathrm{R}^{2}\end{array}$ & B & Beta & Sig \\
\hline Constant & .257 & .252 & 4.545 & & .000 & .353 & .345 & 3.003 & & .000 & .121 & .111 & 7.111 & & .000 \\
\hline F_SEF & & & .109 & .134 & .001 & & & .094 & .109 & .055 & & & .096 & .129 & .035 \\
\hline F_SIT & & & .268 & .294 & .000 & & & .328 & .346 & .000 & & & .167 & .193 & .003 \\
\hline
\end{tabular}


Journal for Educators, Teachers and Trainers

\begin{tabular}{|c|c|c|c|c|c|c|c|c|c|c|c|c|c|c|c|}
\hline & \multicolumn{5}{|c|}{ POOLED DATA } & \multicolumn{5}{|c|}{ USSH } & \multicolumn{5}{|c|}{ UFM } \\
\hline & $\mathrm{R}^{2}$ & $\begin{array}{l}\text { Adjusted } \\
\mathrm{R}^{2}\end{array}$ & B & Beta & Sig & $\mathrm{R}^{2}$ & $\begin{array}{l}\text { Adjusted } \\
\mathrm{R}^{2}\end{array}$ & B & Beta & Sig & $\mathrm{R}^{2}$ & $\begin{array}{l}\text { Adjusted } \\
\mathrm{R}^{2}\end{array}$ & B & Beta & Sig \\
\hline & .276 & .270 & 4.056 & & .000 & .365 & .354 & 2.696 & & .002 & .153 & .139 & 6.327 & & .000 \\
\hline F_SEF & & & .072 & .089 & .036 & & & .049 & .057 & .351 & & & .073 & .099 & .103 \\
\hline F_SIT & & & .223 & .245 & .000 & & & .296 & .312 & .000 & & & .112 & .130 & .057 \\
\hline \multirow[t]{3}{*}{ F_WEN } & & & .098 & .187 & .000 & & & .089 & .156 & .037 & & & .104 & .218 & .002 \\
\hline & $\mathrm{R}^{2}$ & $\begin{array}{l}\text { Adjusted } \\
\mathrm{R}^{2}\end{array}$ & $\mathrm{~B}$ & Beta & Sig & $\mathrm{R}^{2}$ & $\begin{array}{l}\text { Adjusted } \\
\mathrm{R}^{2}\end{array}$ & B & Beta & Sig & $\mathrm{R}^{2}$ & $\begin{array}{l}\text { Adjusted } \\
\mathrm{R}^{2}\end{array}$ & B & Beta & Sig \\
\hline & .348 & .342 & 3.655 & & .000 & .416 & .403 & 2.496 & & .003 & .257 & .242 & 5.328 & & .000 \\
\hline F_SOE & & & .084 & .119 & .011 & & & .161 & .205 & .002 & & & .007 & .011 & .872 \\
\hline F_SEF & & & .044 & .055 & .178 & & & .011 & .013 & .833 & & & .063 & .086 & .134 \\
\hline F_SIT & & & .160 & .175 & .000 & & & .211 & .222 & .000 & & & .098 & .113 & .077 \\
\hline \multirow{2}{*}{ F_UNG } & $\mathrm{R}^{2}$ & $\begin{array}{l}\text { Adjusted } \\
\mathrm{R}^{2}\end{array}$ & $\mathrm{~B}$ & Beta & Sig & $\mathrm{R}^{2}$ & $\begin{array}{l}\text { Adjusted } \\
\mathrm{R}^{2}\end{array}$ & B & Beta & Sig & $\mathrm{R}^{2}$ & $\begin{array}{l}\text { Adjusted } \\
\mathrm{R}^{2}\end{array}$ & B & Beta & Sig \\
\hline & .362 & .355 & 3.231 & & .000 & .421 & .406 & 2.153 & & .012 & .297 & .280 & 4.780 & & .000 \\
\hline F_SOE & & & .076 & .107 & .021 & & & .160 & .205 & .002 & & & -.015 & -.023 & .724 \\
\hline F_SEF & & & .048 & .060 & .137 & & & .011 & .013 & .823 & & & .074 & .100 & .073 \\
\hline F_SIT & & & .144 & .158 & .000 & & & .200 & .211 & .001 & & & .074 & .086 & .171 \\
\hline F_WEN & & & .041 & .079 & .115 & & & .051 & .089 & .224 & & & .030 & .062 & .370 \\
\hline F_UNG & & & .198 & .299 & .000 & & & .178 & .261 & .000 & & & .218 & .341 & .000 \\
\hline F REF & & & .067 & .129 & .001 & & & .049 & .080 & .137 & & & .093 & .216 & .000 \\
\hline
\end{tabular}

